\title{
Perbedaan perubahan berat badan, aktivitas fisik, dan kontrol glukosa darah antara anggota organisasi penyandang diabetes melitus dan non anggota
}

\author{
Dewi Marfu'ah Kurniawati ${ }^{1}$, M. Isnawati ${ }^{2}$
}

\begin{abstract}
Background: Diabetes Mellitus (DM) is a metabolic disease that can not be cured, but the blood glucose levels can be controlled with diabetes management. There is organization in Indonesia for people with diabetes mellitus called Persadia (Persatuan Diabetes Indonesia). Patients who join diabetes peer group is expected to have a better lifestyle.

Objective: To determine differences in weight changes, physical activity, and blood glucose control between Persadia members and non members.

Method: Cross sectional study, with 42 subjects. The subjects were type 2 DM outpatients in Pantiwilasa Citarum Hospital, choosen by consecutive sampling and devided into 2 groups, Persadia members and non members. Weight changes was the difference of current weight with weight from 3 months ago. Physical activity was exercise habits and measured by questionnaire. Blood glucose control was glucose concentrations and measured by HbAlC examination. Statistical analysis used was Chi Square, Kolmogorov-Smirnov, and Fisher.

Result: Persadia group members had more frequent physical activity (52.4\%) than non-member groups (9.6\%). Based on statistical analysis there is a difference of physical activity between Persadia group members and non members $(p=0,042)$. While on weight change $(p=0,537)$ and blood glucose control $(p=0,663)$ there was no difference between Persadia member and non member.

Conclusion: There is a difference between Persadia members and non-members on physical activity. However, there was no difference in weight change and blood glucose control between Persadia and non-member members.
\end{abstract}

Key word: Diabetes Mellitus, Weight Changes, Physical Activity, Blood Glucose Control, Peer Group

\section{ABSTRAK}

Latar Belakang: Diabetes Melitus (DM) merupakan kelompok penyakit metabolik yang tidak dapat disembuhkan, namun kadar glukosa darahnya dapat dikontrol. Di Indonesia terdapat organisasi bagi penyandang DM, yaitu Persadia (Persatuan Diabetes Indonesia). Pasien DM yang mengikuti kegiatan perkumpulan (peer group) diharapkan memiliki gaya hidup lebih baik.

Tujuan: Mengetahui perbedaan perubahan berat badan, aktivitas fisik, dan kontrol glukosa darah antara anggota Persadia dan non anggota.

Metode: Penelitian cross sectional, dengan besar subjek 42 orang. Subjek penelitian adalah pasien DM tipe 2 rawat jalan di RS Pantiwilasa Citarum yang diambil secara consecutive sampling dan dibagi dalam 2 kelompok yaitu anggota Persadia dan non anggota. Perubahan berat badan merupakan selisih berat badan saat ini dengan berat badan 3 bulan yang lalu. Aktivitas fisik merupakan kebiasaan olahraga yang diukur menggunakan kuesioner. Kontrol glukosa darah merupakan konsentrasi glukosa darah yang diukur melalui pemeriksaan HbAlC. Analisis statistik yang digunakan adalah Chi Square, KolmogorovSmirnov, dan Fisher.

Hasil: Kelompok anggota Persadia memiliki aktifitas fisik lebih sering (52,4\%) daripada kelompok non anggota (9,6\%). Berdasarkan analisis statistik ada perbedaan aktifitas fisik antara kelompok anggota Persadia dan non anggota ( $p=0,042)$. Sedangkan pada perubahan berat badan $(p=0,537)$ dan kontrol glukosa darah $(p=0,663)$ tidak ada perbedaan antara anggota Persadia dan non anggota.

Simpulan: Terdapat perbedaan antara anggota Persadia dan non anggota pada aktivitas fisik. Namun, tidak ada perbedaan perubahan berat badan dan kontrol glukosa darah antara anggota Persadia dan non anggota.

Kata kunci: Diabetes mellitus, perubahan BB, aktifitas fisik, kontrol glukosa darah, peer group

\section{PENDAHULUAN}

Diabetes Mellitus (DM) merupakan suatu kelompok penyakit metabolik dengan karakteristik

\footnotetext{
1. Departemen Ilmu Gizi, Fakultas Kedokteran, Universitas Diponegoro (email korespondensi dewimarfuahkurniawati@gmail.com)

2. Jurusan Gizi Politeknik Kesehatan Kemenkes Semarang
}

hiperglikemia yang terjadi karena kelainan sekresi insulin, kerja insulin atau kedua-duanya. ${ }^{1}$ World Health Organization (WHO) memprediksi kenaikan jumlah pasien DM di Indonesia dari 8,4 juta pada tahun 2000 menjadi sekitar 21,3 juta pada tahun 2030. Hasil Riset Kesehatan Dasar (Riskesdas) tahun 2007, menunjukkan bahwa penyebab kematian akibat DM pada kelompok umur 45-54 tahun di daerah perkotaan menduduki ranking ke-2 yaitu $14,7 \%$, sedangkan di 
daerah pedesaan, DM menduduki ranking ke-6 yaitu $5,8 \% .^{2}$

DM tidak dapat disembuhkan, namun kadar glukosa darahnya dapat dikontrol untuk memperlambat terjadinya komplikasi. ${ }^{3}$ Sebuah penelitian tentang kontrol glukosa darah pada pasien DM di poliklinik RS PKU Muhammadiyah Yogyakarta pada tahun 2008 menunjukkan, sebanyak $54,3 \%$ pasien DM tipe 2 memiliki kontrol glukosa darah yang buruk selama 3 bulan. ${ }^{4}$ Kadar glukosa darah dapat dikontrol dengan pengelolaan DM yang baik. $^{5}$ Empat pilar utama pengelolaan DM adalah perencanaan makan, latihan jasmani, obat berkhasiat hipoglikemik, dan penyuluhan. ${ }^{6}$ Namun, beberapa penelitian tentang kontrol glukosa darah di RS, menunjukkan bahwa kadar glukosa darah penyandang DM tidak terkontrol.

Salah satu hal yang perlu dilakukan untuk mengatasi ketidakpatuhan penyandang DM adalah memberikan edukasi gizi. Penyandang DM yang mempunyai pengetahuan cukup, diharapkan akan mengubah perilakunya agar dapat mengendalikan kondisi penyakit. ${ }^{7}$ Peer group membantu meningkatkan pengetahuan, karena para anggota bisa berbagi pengetahuan, pengalaman, emosional, atau sosial satu sama lain. ${ }^{8}$ Sebuah penelitian tentang edukasi dan konseling gaya hidup di Belanda menunjukkan bahwa setelah diberikan intervensi dan dilakukan pengamatan selama 5 tahun, anggota yang mengikuti konseling kelompok mangalami peningkatan gaya hidup yang lebih baik daripada konseling pribadi. ${ }^{9}$

Di Indonesia terdapat organisasi bagi penyandang DM, yaitu Persadia (Persatuan Diabetes Indonesia). Penyandang DM yang menjadi anggota Persadia diharapkan memiliki pengetahuan dan kesadaran untuk memelihara kesehatan secara lebih baik. Kegiatan rutin yang dilakukan oleh anggota Persadia adalah pemeriksaan kadar glukosa darah setiap 1 bulan sekali, pemeriksaan tekanan darah setiap 1 bulan sekali, dan senam yang diadakan 1 kali dalam seminggu sebagai upaya meningkatkan aktivitas fisik.

Peningkatan aktivitas fisik seperti olahraga, akan meningkatkan sensitivitas hormon insulin, sehingga glukosa darah lebih terkontrol. Penelitian tentang pasien DM tipe 2 yang mengikuti senam, memiliki kontrol glukosa darah lebih baik daripada pasien yang tidak melakukan senam. ${ }^{10}$ Penelitian lain menemukan bahwa intervensi gaya hidup berupa latihan selama 150 menit per minggu disertai dengan diet, dapat menurunkan berat badan sebesar $5-7 \%$ dan menurunkan keparahan impaired glucose tolerance (IGT) pada DM tipe 2 sebesar $58 \% .^{11}$

Pengelolaan DM juga bertujuan untuk mengatur berat badan, karena beberapa penyandang
DM yang memiliki masalah berat badan, baik kelebihan maupun kekurangan berat badan. Sebuah studi menyebutkan bahwa penyandang DM tipe 2 obesitas yang mengalami penurunan berat badan 5 $10 \%$, akan lebih baik dalam mengontrol diabetesnya. ${ }^{11}$ Berdasarkan hal tersebut maka analisis perbedaan perubahan berat badan, aktivitas fisik, dan kontrol glukosa darah antara anggota organisasi penyandang DM dan non anggota perlu dilakukan.

\section{BAHAN DAN METODE}

Penelitian dilakukan di RS Pantiwilasa Citarum pada bulan September - November 2011. Desain penelitian adalah cross sectional dengan subjek sebanyak 42 orang. Subjek penelitian dibagi dalam dua kelompok, yaitu kelompok anggota Persadia sebanyak 21 orang dan non anggota sebanyak 21 orang. Subjek penelitian yang memenuhi kriteria inklusi diambil secara consecutive sampling. Kriteria inklusi subjek penelitian non anggota adalah pasien rawat jalan berumur 35-70 tahun yang telah didiagnosa menyandang DM tipe 2 minimal 3 bulan sebelum penelitian, dan mengkonsumsi obat penurun kadar glukosa darah. Sedangkan kriteria inklusi subjek penelitian anggota Persadia adalah pasien rawat jalan berumur 35-70 tahun yang telah didiagnosa menderita DM tipe 2 minimal 3 bulan sebelum penelitian, mengkonsumsi obat penurun kadar glukosa darah dan mengikuti kegiatan di Persadia unit RS Pantiwilasa Citarum minimal 3 bulan terakhir.

Data yang dikumpulkan berupa data kualitatif dan kuantitatif. Data kualitatif meliputi gambaran kegiatan Persadia di RS Pantiwilasa Citarum. Sedangkan data kuantitatif meliputi data antropometri, kuesioner kebiasaan olahraga dan data pemeriksaan HbA1C. Perubahan berat badan merupakan selisih berat badan saat ini dengan berat badan terdahulu (3 bulan yang lalu). Aktivitas fisik merupakan kebiasaan olahraga yang diperoleh dari pengisian kuesioner. Kuesioner tersebut berisi empat pertanyaan yang berisi tentang jenis, durasi, dan frekuensi olahraga yang sering dilakukan. ${ }^{12}$ Kontrol glukosa darah merupakan konsentrasi glukosa darah dalam tubuh yang diperiksa dengan pemeriksaan $\mathrm{HbA} 1 \mathrm{C} .{ }^{13}$

Pengolahan dan analisis data dilakukan dengan menggunakan program komputer. Analisis univariat meliputi jenis kelamin, pendidikan terakhir, pekerjaan, kelompok umur, berat badan 3 bulan yang lalu, berat badan saat ini dan nilai HbA1C. Sedangkan analisis bivariat meliputi perubahan berat badan menggunakan uji Chi Square, Kolmogorof Smirnov untuk data aktifitas fisik, dan Fisher untuk data kontrol glukosa darah. 


\section{HASIL}

\section{Gambaran Penyandang DM Anggota Persadia dan Non Anggota}

Penyandang DM dianjurkan melakukan kontrol rutin satu bulan sekali agar status kesehatannya dapat dipantau oleh dokter. Namun pada beberapa pasien yang menderita DM dengan ulkus, kontrol dilakukan satu minggu sekali untuk pembersihan luka. Persadia unit RS Pantiwilasa Citarum diadakan sejak tahun 2006. Kegiatan Persadia di RS Pantiwilasa Citarum meliputi seminar, senam, dan lomba-lomba. Kegiatan pasca senam pada minggu pertama dilakukan pemeriksaan tekanan darah dan minggu keempat dilakukan pemeriksaan glukosa darah. Pemeriksaan glukosa darah dilakukan untuk memantau kadar glukosa darah anggota Persadia. Kegiatan seminar dilakukan minimal setiap 6 bulan sekali yang berisi tentang penanganan DM serta komplikasi yang mungkin terjadi pada penyandang DM.

\section{Karakteristik Subjek Penelitian}

Berdasarkan Tabel 1 terlihat bahwa sebagian besar subjek penelitian adalah perempuan $(52,4 \%)$. Pendidikan terakhir paling banyak adalah SMA, yaitu $42,8 \%$ pada kelompok anggota Persadia dan 61,9\% pada non anggota. Subjek penelitian kelompok anggota Persadia $(52,4 \%)$ masuk dalam kelompok umur 65 - 74 tahun, sedangkan pada kelompok non anggota subjek penelitian tersebar secara merata pada semua kelompok umur.

Sebagian besar subjek penelitian pada kedua kelompok tidak bekerja karena pensiun dan beberapa diantaranya adalah ibu rumah tangga. Namun, jumlah subjek penelitian pada kelompok anggota Persadia yang masih bekerja baik sebagai pegawai swasta dan PNS lebih tinggi (47,6\%) jika dibandingkan dengan kelompok non anggota $(23,8 \%)$. Subjek penelitian yang masih bekerja dan memiliki penghasilan tetap setiap bulan akan memiliki kehidupan yang lebih mapan, sehingga akan mempengaruhi pemilihan jenis dan jumlah makanan.

Tabel 1. Deskripsi Subjek Penelitian Berdasarkan Jenis Kelamin, Pendidikan, Pekerjaan, Dan Kelompok Umur

\begin{tabular}{lllll}
\hline \multirow{2}{*}{ Karakteristik Subjek } & \multicolumn{2}{c}{ Anggota Persadia $(\mathbf{n = 2 1})$} & \multicolumn{2}{c}{ Non Anggota $(\mathbf{n = 2 1})$} \\
\cline { 2 - 5 } & $\mathbf{n}$ & $\mathbf{\%}$ & $\mathbf{n}$ & $\mathbf{\%}$ \\
\hline Jenis Kelamin & 10 & 47,6 & 10 & 47,6 \\
Laki-laki & 11 & 52,4 & 11 & 52,4 \\
Perempuan & & & & \\
Pendidikan Terakhir & 2 & 9,5 & 4 & 19,0 \\
SD & 3 & 14,3 & - & - \\
SMP & 9 & 42,8 & 13 & 61,9 \\
SMA & 6 & 28,6 & 1 & 4,8 \\
Akademi & 1 & 4,8 & 3 & 14,3 \\
PT & & & & \\
Pekerjaan & 11 & 52,4 & 16 & 76,2 \\
Tidak bekerja & 8 & 38,1 & 3 & 14,3 \\
Swasta & 2 & 9,5 & 2 & 9,5 \\
PNS & & & & \\
Kelompok umur & 1 & 4,8 & 5 & 23,8 \\
35-44 tahun & 3 & 14,3 & 6 & 28,6 \\
45-54 tahun & 6 & 28,6 & 7 & 33,3 \\
55-64 tahun & 11 & 52,4 & 3 & 14,3 \\
65-74 tahun & & & & \\
\hline
\end{tabular}

Tabel 2 menunjukkan beberapa subjek mengalami perubahan berat badan yang tidak sesuai dengan target. Aktivitas fisik pada kelompok anggota Persadia sebagian besar $(52,4 \%)$ masuk dalam kategori sering. Beberapa subjek kelompok non anggota $(33,3 \%)$ menyatakan bahwa mereka tidak pernah melakukan olahraga karena kesibukan pekerjaan dan 57,1\% masuk dalam kategori kadang kadang. Jenis olahraga yang dilakukan adalah senam atau jogging dengan frekuensi $1-2$ kali dalam seminggu dengan durasi kurang dari 30 menit.
Jumlah subjek anggota Persadia yang memiliki nilai HbA1C tidak terkontrol lebih banyak $(19,0 \%)$ daripada kelompok non anggota $(9,5 \%)$. Subjek penelitian pada kelompok anggota Persadia sebagian besar $(52,4 \%)$ masuk dalam kelompok umur 65-74 tahun, sedangkan pada kelompok non anggota, subjek tersebar merata pada semua kelompok umur dan yang masuk kelompok umur 65-74 tahun hanya $(14,3 \%)$. 
Tabel 2. Deskripsi perubahan berat badan, aktivitas fisik, dan kontrol glukosa darah

\begin{tabular}{|c|c|c|c|c|}
\hline \multirow{2}{*}{ Karakteristik Subjek } & \multicolumn{2}{|c|}{$\begin{array}{c}\text { Anggota Persadia } \\
(n=21)\end{array}$} & \multicolumn{2}{|c|}{ Non Anggota $(n=21)$} \\
\hline & $\mathbf{N}$ & $\%$ & $\mathbf{n}$ & $\%$ \\
\hline \multicolumn{5}{|l|}{ Perubahan BB } \\
\hline Sesuai target & 9 & 42,9 & 11 & 52,4 \\
\hline Tidak sesuai target & 12 & 57,1 & 10 & 47,6 \\
\hline \multicolumn{5}{|l|}{ Melakukan olahraga } \\
\hline $\mathrm{Ya}$ & 21 & 100 & 14 & 66,7 \\
\hline Tidak & - & - & 7 & 33,3 \\
\hline \multicolumn{5}{|l|}{ Jenis Olahraga } \\
\hline Senam, jogging & 21 & 100 & 12 & 85,7 \\
\hline Bulu tangkis, tenis meja & - & - & 2 & 14,3 \\
\hline Sepak bola, basket, berenang & - & - & - & - \\
\hline \multicolumn{5}{|l|}{ Frekuensi Olahraga } \\
\hline $1-2 \mathrm{kali} / \mathrm{minggu}$ & 10 & 47,6 & 9 & 64,3 \\
\hline $3-5 \mathrm{kali} / \mathrm{minggu}$ & 11 & 52,4 & 3 & 21,4 \\
\hline Setiap hari & - & - & 2 & 14,3 \\
\hline \multicolumn{5}{|l|}{ Durasi Olahraga } \\
\hline$<30$ menit & - & - & 10 & 71,4 \\
\hline $30-60$ menit & 21 & 100 & 4 & 28,6 \\
\hline$>60$ menit & - & - & - & - \\
\hline \multicolumn{5}{|l|}{ Aktivitas Fisik } \\
\hline Tidak pernah & - & - & 7 & 33,3 \\
\hline Kadang-kadang & 10 & 47,6 & 12 & 57,1 \\
\hline Sering & 11 & 52,4 & 2 & 9,6 \\
\hline \multicolumn{5}{|l|}{ Kontrol glukosa darah } \\
\hline Terkontrol & 17 & 81,0 & 19 & 90,5 \\
\hline Tidak terkontrol & 4 & 19,0 & 2 & 9,5 \\
\hline
\end{tabular}

Perbedaan Perubahan Berat Badan, Aktivitas Fisik, dan Kontrol Glukosa Darah Antara Kelompok Anggota Persadia Dan Non Anggota

Hasil uji statistik menunjukkan tidak ada perbedaan pada perubahan berat badan $(p>0,05)$ dan kontrol glukosa darah $(\mathrm{p}>0,05)$. Selain itu subjek yang mengalami perubahan berat badan sesuai target pada kelompok anggota Persadia ternyata lebih sedikit $(42,9 \%)$ daripada kelompok non anggota $(52,4 \%)$ dan jumlah subjek kelompok anggota Persadia yang masih bekerja lebih tinggi $(47,6 \%)$ daripada kelompok non anggota $(23,8 \%)$. Hasil wawancara pada subjek menunjukkan bahwa beberapa subjek memilih roti, kue kering dan gorengan oleh anggota persadia sebagai makanan selingan akan mempengaruhi kadar glukosa darah setelah makan. Hasil uji statistik menunjukkan adanya perbedaan bermakna pada aktifitas fisik antara kelompok anggota Persadia dan non anggota $(\mathrm{p}<0,05)$.

Tabel 3. Perubahan Berat Badan, Aktivitas Fisik, dan Kontrol Glukosa Darah Antara Kelompok Anggota Persadia Dan Non Anggota

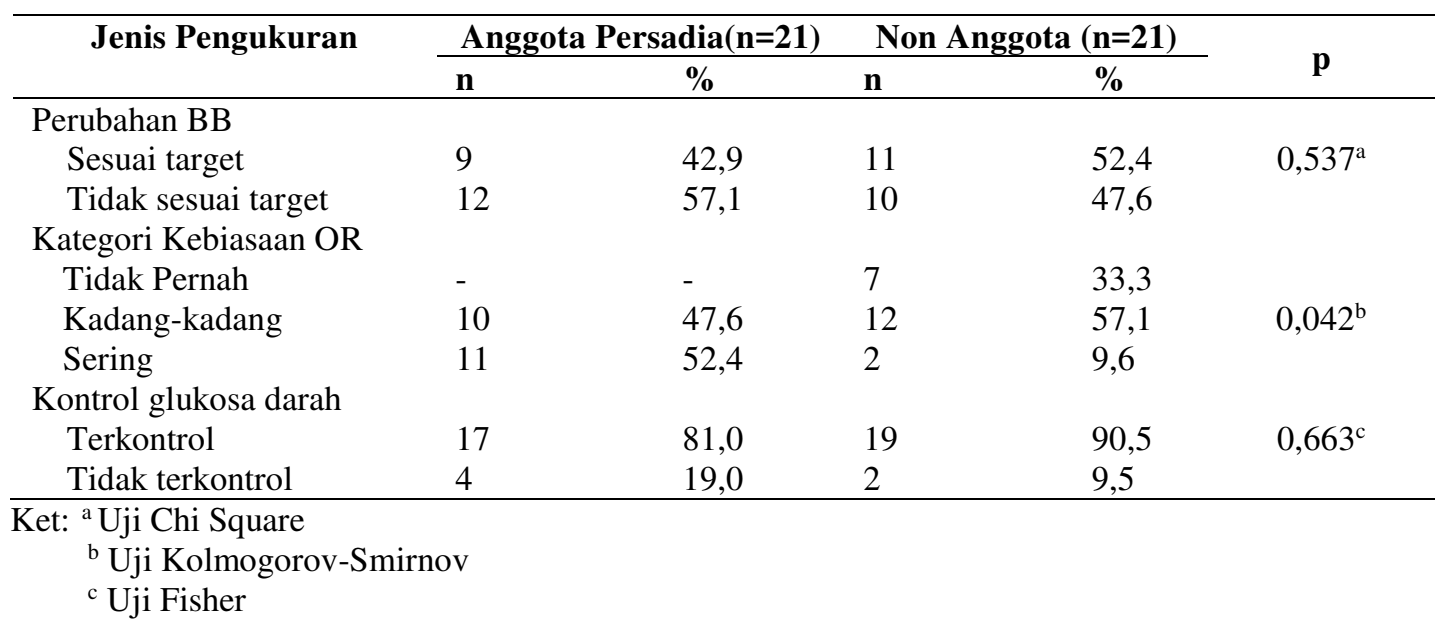




\section{PEMBAHASAN}

Penyandang DM yang memiliki masalah berat badan, baik kelebihan maupun kekurangan berat badan telah diberi arahan oleh dokter untuk mengelola berat badan. Beberapa subjek mengalami perubahan berat badan yang tidak sesuai dengan target. Penurunan berat badan dapat terjadi karena energi yang dikeluarkan lebih besar daripada asupan makanan. ${ }^{14}$ Penurunan berat badan pada penyandang DM juga bisa terjadi karena hilangnya otot dan cadangan lemak tubuh. Kelainan metabolisme glukosa pada penyandang DM menyebabkan makanan atau minuman mengalami kesulitan ketika masuk ke dalam sel- sel tubuh. Sedangkan sel - sel tubuh tetap membutuhkan energi, sehingga lemak dan protein akan dipecah untuk menghasilkan energi. ${ }^{7}$

Aktivitas fisik pada kelompok non anggota tergolong kurang karena tidak pernah atau jarang melakukan olahraga. Kurangnya aktivitas fisik merupakan salah satu faktor terjadinya peningkatan berat badan, karena energi yang dikeluarkan lebih kecil daripada asupan makanan. ${ }^{14}$ Anggota kelompok Persadia sebagian besar melakukan olahraga endurans seperti senam atau jogging selama 3 - 5 kali dalam satu minggu dengan durasi $30-60$ menit. Pelaksanaan olahraga telah sesuai dengan prinsip latihan fisik dari segi frekuensi, durasi, maupun jenis olahraga. ${ }^{15}$

Subjek anggota Persadia yang memiliki nilai HbA1C tidak terkontrol lebih banyak (19,0\%) daripada kelompok non anggota $(9,5 \%)$. Nilai HbA1C menggambarkan glukosa darah terakumulasi, pada kondisi hiperglikemia yang berkepanjangan, kadar HbA1C dapat meningkat hingga $18-20 \%{ }^{16}$ Salah satu faktor yang mempengaruhi nilai $\mathrm{HbA} 1 \mathrm{C}$ adalah umur. Beberapa studi menunjukkan bahwa terdapat perubahan HbA1C sekitar $0,1 \%$ per dekade setelah umur 30 tahun. ${ }^{17}$ Penyandang DM yang menjadi anggota Persadia diharapkan memiliki kontrol glukosa darah yang lebih baik. Persadia memiliki program pemeriksaan glukosa darah tiap bulan, namun kemungkinan bias pada pemeriksaan glukosa darah termasuk tinggi, karena dilakukan sesaat setelah senam, sehingga kadar glukosa darah pada glukometer menunjukkan hasil yang lebih rendah.

Pemilihan roti, kue kering dan gorengan oleh anggota persadia sebagai makanan selingan akan mempengaruhi kadar glukosa darah setelah makan. Makanan sumber karbohidrat akan dicerna dan diabsorbsi dengan kecepatan berbeda-beda sehingga karbohidrat dengan jumlah yang sama tidak memberikan efek yang sama dalam hal kadar glukosa darah, produksi insulin, maupun kadar lemak darah. ${ }^{18}$ Asupan asam lemak tertentu berpengaruh pada metabolisme glukosa yang menyebabkan terjadinya perubahan komposisi membran fosfolipid dan fungsi reseptor insulin. ${ }^{19}$ Program peningkatan aktivitas fisik yang dilakukan oleh Persadia yaitu kegiatan senam yang dilakukan satu kali dalam seminggu dan peningkatan pengetahuan melalui seminar ternyata dapat mengubah gaya hidup anggotanya terutama dalam hal kebiasaan olahraga.

Prinsip latihan fisik bagi penyandang DM sama dengan prinsip latihan fisik secara umum, yaitu frekuensi, durasi, dan jenis. Pada penyandang DM latihan fisik yang dipilih sebaiknya latihan fisik yang disenangi, selain dapat meningkatkan kesehatan, juga dapat meningkatkan kebugaran penyandang DM. Latihan fisik yang dilakukan sebaiknya melibatkan otot - otot besar dan sesuai dengan keinginan agar manfaat latihan fisik dapat dapat dirasakan secara terus menerus..$^{15}$

Frekuensi latihan fisik bagi penyandang DM sebaiknya dilakukan secara teratur 3 - 5 kali dalam satu minggu dan durasi latihan fisik yang dilakukan selama 30 - 60 menit. Latihan fisik yang dipilih memiliki intensitas ringan dan sedang yaitu sebesar $60 \%-70 \%$ maximum heart rate (MHR). Jenis latihan fisik yang dipilih adalah jenis latihan fisik endurans seperti jogging, berenang, bersepeda, senam, dan latihan fisik endurans lainnya. ${ }^{15}$

\section{SIMPULAN}

Subjek penelitian pada kelompok anggota Persadia yang sering melakukan olahraga lebih tinggi $(52,4 \%)$ daripada non anggota $(9,6 \%)$. Hasil uji statistik menunjukkan tidak terdapat perbedaan bermakna pada perubahan berat badan dan kontrol glukosa darah antara anggota Persadia dan non anggota $(\mathrm{p}>0,05)$. Sebaliknya, terdapat perbedaan aktifitas fisik antara anggota persadia dan non anggota $(\mathrm{p}=0,042)$.

\section{SARAN}

1. Bagi penyandang DM baik yang menjadi anggota organisasi maupun tidak, pengelolaan DM seperti pengaturan makan dan peningkatan aktivitas fisik perlu dilakukan untuk membantu kontrol glukosa darah dan mengurangi resiko terjadinya komplikasi.

2. Penyandang DM yang menjadi anggota Persadia sebaiknya tidak hanya menempatkan Persadia sebagai gaya hidup, tetapi lebih menempatkan Persadia sebagai media untuk membantu pengelolaan DM yang lebih baik. 


\section{DAFTAR PUSTAKA}

1. Gustaviani R. Diagnosis dan Klasifikasi Diabetes Melitus. Buku Ajar Ilmu Penyakit Dalam. Jakarta: Pusat Penerbitan Departemen Ilmu Penyakit Dalam FKUI ; 2007: 1857

2. Depkes RI. Tahun 2030 Prevalensi Diabetes Melitus Di Indonesia Mencapai 21,3 Juta Orang. Jakarta: Balitbang [online] 2007 [citied 2011 April 4]. Available from: http://www.depkes.go.id/

3. Waspadji S, Suyono S, Sukardji K, Hartati. Pengkajian Status Gizi Studi Epidemiologi. Jakarta: Pusat Diabetes Mellitus dan Lipid RSCM; 2003

4. Rinto Nidya A, Sunarto, Ika Fidianingsih. Hubungan Antara Sikap, Perilaku dan Partisipasi Keluarga Terhadap Kadar Gula Darah Penderita Diabetes Melitus Tipe 2 di RS PKU Muhammadiyah Yogyakarta Bulan Januari - Juli 2008. [skripsi]. Yogyakarta. Universitas Islam Indonesia; 2008

5. Tandra H. Panduan Lengkap Mengenal dan Mengatasi DM dengan Cepat dan Mudah. Jakarta: Gramedia Pustaka Umum; 2008.

6. Sarwono W. Diabetes Mellitus: Mekanisme Dasar dan Pengelolaannya yang Rasional dalam: Penatalaksanaan Diabetes Melituss Terpadu. Jakarta: FKUI; 2002. p.31-40

7. Perkumpulan Endokrinologi Indonesia (PERKENI). Konsensus Pengelolaan Diabetes Melitus Tipe 2 di Indonesia. Jakarta; 2006.

8. Shery Mead, David Hilton. Peer Support: A Theoretical Perspective. Department of Mental Health \& Developmental Services. 2006; 25:8599.

9. Toff, Ulla et all. The Effect Of Adding GroupBased Counselling To Individual Lifestyle Counselling On Changes In Dietary Intake. The Inter99 Study - A Randomized Controlled Trial. International Journal of Behavioral Nutrition and Physical Activity. 2008; 14(5):3251-27

10. Bweir S, Al-Jarrah M, Almalty AM, et al. Resistance Exercise Training Lowers Hbalc More Than Aerobic Training In Adults With Type 2 Diabetes. Diabetol Metab Syndrom ; 2009;1:27

11. Ronald J Sigal. Physical Activity/Exercise And Type 2 Diabetes: A Consensus Statement From The American Diabetes Association. Diabetes Care; 2006. 17(3):1-24

12. Itsnainiah $\mathrm{T} \cdot$ Hubungan antara IMT, Kadar $\mathrm{Hb}$ dan Kebiasaan Olahraga dengan Tingkat Kesegaran Jasmani pada Lansia [Skripsi]. Semarang: Ilmu Gizi UNDIP. 2007.
13. Horton, Erward S. measuring Glycemic Control: Translating HbA1C into Estimated Average Glucose. [online]. 2010 [citied 2011 Desember 6]; Available from: http:/professional.diabetes.org

14. Purbalena M, Endah SR, Hemi S. Dukungan Keluarga Dan Jadwal Makan Sebelum Edukasi Berhubungan Dengan Kepatuhan Jadwal Makan Pasien Diabetes Melitus (DM) Tipe 2 Rawat Jalan Yang Mendapat Konseling Gizi. Jurnal Gizi Klinik Indonesia. 2010: 74-79

15. Ermita I Ilyas. Olahraga Bagi Diabetisi. Dalam: Penatalaksanaan: Diabetes Melitus Terpadu. Jakarta: FKUI; 2002. 71-75

16. Yulianti Kusniyah, Nursiswati, Urip Rahayu. Hubungan Tingkat Self Care Dengan Tingkat HbA1C Pada Klien Diabetes Melitus Tipe 2 Di Poliklinik Endokrin RSUP Dr. Hasan Sadikin Bandung. Jurnal Medika. 2010;1-23

17. American Diabetes Association. A1C Level and Future Risk of Diabetes: A Systematic Review. Diabetes Care; 2010. 33:1665-1673

18. Suryanto. Memahami Psikologi Massa dan Penanganannya [online] 2008 [citied 2011 Desember 22]; Available from: http://web.unair.ac.id/2008/12/03/memahamipsikologi-massa-dan-penanganannya/

19. Ghaderian N, Noushin MF, Firoozeh S, Gholam HS, Ali M, Maryam M. Is There Any Relationship Between The Type Of Dietary Fat And Blood Glucose? Results Of Isfahan Healthy Heart Program. Arya Atherosclerosis Journal. 2007 ; 3(3) : 162-7. 